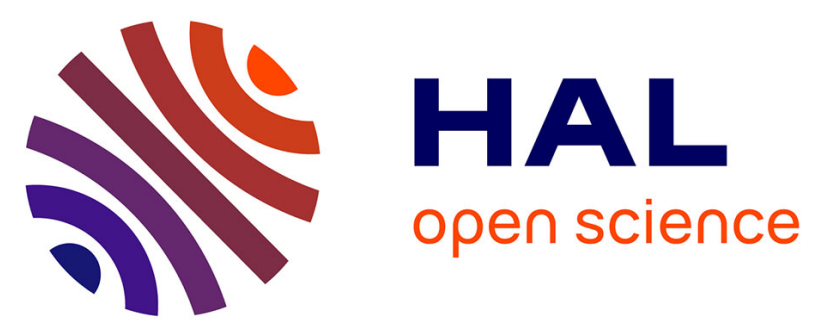

\title{
The impact of African aridity on the isotopic signature of Atlantic deep waters across the Middle Pleistocene Transition
}

\author{
Bruno Malaizé, Elsa Jullien, Amandine Tisserand, Charlotte Skonieczny, \\ Francis Grousset, Frédérique Eynaud, Catherine Kissel, Jérôme Bonnin, \\ Svenja Karstens, Philippe Martinez, et al.
}

\section{To cite this version:}

Bruno Malaizé, Elsa Jullien, Amandine Tisserand, Charlotte Skonieczny, Francis Grousset, et al.. The impact of African aridity on the isotopic signature of Atlantic deep waters across the Middle Pleistocene Transition. Quaternary Research, 2012, 77 (1), pp.182-191. 10.1016/j.yqres.2011.09.010 . hal-03329205

\section{HAL Id: hal-03329205 \\ https://hal.science/hal-03329205}

Submitted on 30 Aug 2021

HAL is a multi-disciplinary open access archive for the deposit and dissemination of scientific research documents, whether they are published or not. The documents may come from teaching and research institutions in France or abroad, or from public or private research centers.
L'archive ouverte pluridisciplinaire HAL, est destinée au dépôt et à la diffusion de documents scientifiques de niveau recherche, publiés ou non, émanant des établissements d'enseignement et de recherche français ou étrangers, des laboratoires publics ou privés. 
1 The impact of African aridity on the isotopic signature of Atlantic deep waters across the Middle Pleistocene Transition

4 Bruno Malaizé a,, Elsa Jullien a , Amandine Tisserand ${ }^{\mathrm{a}, \mathrm{b}}$, Charlotte Skonieczny ${ }^{\mathrm{c}}$, Francis

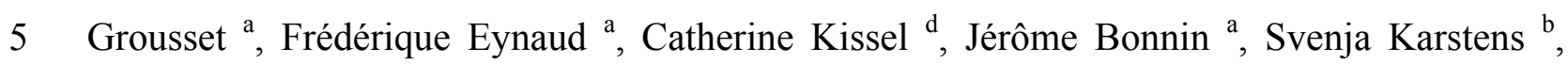
6 Philippe Martinez ${ }^{\mathrm{a}}$, Aloys Bory ${ }^{\mathrm{c}}$, Viviane Bout-Roumazeilles ${ }^{\mathrm{c}}$, Thibaut Caley ${ }^{\mathrm{a}}$, Xavier 7 Crosta $^{\text {a }}$, Karine Charlier ${ }^{\text {a }}$, Linda Rossignol ${ }^{a}$, José-Abel Flores ${ }^{e}$, Ralph Schneider ${ }^{\mathrm{f}}$

8 a UMR CNRS 5805 EPOC, Université Bordeaux I, 33405 Talence, France

9 b Department of Earth sciences, University of Bergen, Realfagb, Allègt. 41, Bergen, Bjerknes Centre for Climate Research, BCCR, Allègaten 55, 5007 Bergen, Norway

11 c FRE CNRS 3298 GEOSYSTEMES, Université de Lille I, 59655 Villeneuve d'Ascq, France d Laboratoire des Sciences du Climat et de l'Environnement/IPSL, CEA/CNRS/UVSQ, 13 Avenue de la Terrasse, Bat 12, 91198 Gif-sur-Yvette Cedex, France

14 e Departamento de Geología, Universidad de Salamanca, 37008, Salamanca, Spain f Institut fuer Geowissenschaften, Christian-Albrechts-Universitaet, 10/24118 Kiel, Germany * Corresponding author at: University Bordeaux1, UMR 5805 EPOC, France. Fax:+335 5684 08 48, E-mail address: b.malaize@epoc.u-bordeaux1.fr (B. Malaizé).

Keywords: Mid-Pleistocene Transition - Atlantic deep waters - Foraminifera - Stable isotopes - African aridity - Ti

\section{Abstract}

A high resolution analysis of benthic foraminifera as well as of aeolian terrigenous proxies extracted from a $37 \mathrm{~m}$-long marine core located off the Mauritanian margin spanning the last $\sim 1.2 \mathrm{Ma}$, documents the possible link between major continental environmental changes with a shift in the isotopic signature of deep waters around 1.0-0.9 Ma, within the so-called MidPleistocene Transition (MPT) time period. The increase in the oxygen isotopic composition of deep waters, as seen through the benthic foraminifera $\delta^{18} \mathrm{O}$ values, is consistent with the growth of larger ice sheets known to have occurred during this transition. Deep-water mass 
$\delta^{13} \mathrm{C}$ changes, also estimated from benthic foraminifera, show a strong depletion for the same time interval.

This drastic change in $\delta^{13} \mathrm{C}$ values is concomitant with a worldwide $0.3 \%$ o decrease observed in the major deep oceanic waters for the MPT time period. The phase relationship between aeolian terrigeneous signal increase and this $\delta^{13} \mathrm{C}$ decrease in our record, as well as in other paleorecords, supports the hypothesis of a global aridification amongst others processes to explain the deep-water masses isotopic signature changes during the MPT. In any case, the isotopic shifts imply major changes in the end-member $\delta^{18} \mathrm{O}$ and $\delta^{13} \mathrm{C}$ values of deep waters.

\section{Introduction}

During the Mid-Pleistocene Transition (MPT), which extends from 1.25 to $0.7 \mathrm{Ma}$ (Clark et al., 2006, approximately centered around 0.9 Ma), drastic changes were observed in the glacial isotopic composition of deep-water masses of the Equatorial Atlantic Ocean (enriched $\delta^{18} \mathrm{O}$ values and depleted $\delta^{13} \mathrm{C}$ values) (Flower et al., 2000; Schefuß et al., 2003; Raymo et al., 2004). Similar shifts in isotopic values (i.e., enriched $\delta^{18} \mathrm{O}$ values and depleted $\delta^{13} \mathrm{C}$ values) were observed in cores from different oceanic basins, highlighting the global aspect of such changes (Raymo et al., 1997; deMenocal, 2004; Ravelo et al., 2004; Lisiecki and Raymo, 2005; Hoogakker et al., 2006). Global trends are only apparent in deep-water signatures. Conversely, records of surface conditions vary: cooling is shown in the equatorial Atlantic (Marlow et al., 2000), while stable sea-surface temperatures are observed in the tropical Pacific warm pool (deGaridel-Thoron et al., 2005) at the same time. The global $\delta^{18} \mathrm{O}$ benthic enrichment mainly results from the build up of large continental ice sheets at high latitudes. The decrease in $\delta^{13} \mathrm{C}$ benthic values $(>0.3 \%$ ) between 1.1 and $0.9 \mathrm{Ma}$ has been attributed to a net addition of a 12C-enriched reservoir into the ocean (Raymo et al., 1997). Two main candidates were proposed: (1) marine organic matter exposed on continental shelves as sea level dropped, or (2) carbon input from the terrestrial biosphere reservoir. The first hypothesis suggests an increase in the mean ocean nutrient content, implying changes in the Atlantic- Pacific oceanic $\delta^{13} \mathrm{C}$ gradient. As no such changes are observed in the inter-basin $\delta^{13} \mathrm{C}$ gradient nor in the Redfield nutrients, the first hypothesis has been disregarded. This left the second hypothesis, suggesting, without other robust arguments, a global increase in aridity after 0.9 Ma (Raymo et al., 1997). A global carbon isotope budget, applied to glacialinterglacial climatic shifts (Maslin and Thomas, 2003), estimated the effect of different parameters such as terrestrial biomass volume and carbon isotopic changes $(\mathrm{C} 3 / \mathrm{C} 4)$, together 
with changes due to exchange of gas hydrates. This study proposed an average shift in the global oceanic $\delta^{13} \mathrm{C}$ values of about $0.3 \%$ obetween the last glacial maximum (LGM) and the Holocene, reappraising previous average estimates of $\sim 0.4 \%$ (Curry et al., 1988; Duplessy et al., 1988). Maslin and Thomas (2003) highlighted here the important consequence of bigger ice sheets on the receding of terrestrial biomass and the impact on the global carbon isotope budget. For the MPT, global models (e.g., Hoogakker et al., 2006) have suggested that such oceanic $\delta^{13} \mathrm{C}$ fluctuations could result from concomitant changes in the burial fluxes of organic and inorganic carbon. On the Atlantic coast of Africa, previous studies on marine records, focusing on the MPT, revealed environmental changes over the continent, linked to atmospheric changes, bringing new pieces of evidence for aridification (Dupont et al., 2001; Schefuß et al., 2003) and wind intensification (Marlow et al., 2000). DeMenocal has even suggested that such changes could have influenced African hominid evolution (deMenocal, 2004).

In addition to this peculiar isotopic shift occurring during the MPT, isotopic changes are observed in Equatorial Atlantic deep-water masses on orbital time scales (Duplessy et al., 1980; Duplessy and Shackleton, 1985; Curry et al., 1988; Oppo and Lehman, 1993; Raymo et al., 1997; Flower et al., 2000; Curry and Oppo, 2005). In the modern Atlantic Ocean and more generally during interglacial periods, the northward-flowing surface water becomes denser and sinks as the southward-flowing North Atlantic Deep Water (NADW). This deepwater mass is characterized by rather $\delta^{18} \mathrm{O}$ values $(\sim 3 \%)$ due to reduced continental ice sheet volume, and by high $\delta^{13} \mathrm{C}$ values (N1\%) resulting from young waters sinking from the surface, after marine productivity has removed nutrients (PO3, NO3) and 12C, enriching it in ${ }^{13} \mathrm{C}$ (Broecker and Peng, 1982; Curry et al., 1988). This carbon isotopic signature can be traced as far south as the equatorial region, at depths of about 2500-3000 mbs (Flower et al., 2000) (Fig. 1). The southern part of the deep Atlantic Ocean hosts Lower Circumpolar Deep Water (LCDW), originating from the Southern Ocean. This watermass is characterized by lower $\delta^{13} \mathrm{C}$ values (between 0.5 and 0\%o, after Kroopnick, 1985). Because these southern deep waters have been isolated from the surface for a long time, the continuous oxidation of low$\delta^{13} \mathrm{C}$ organic matter at depth has lowered its $\delta^{13} \mathrm{C}$ value.

During a glacial period, the build-up of huge continental ice sheets influences the dynamics of this deep-water circulation, reducing NADW formation, and delivering it to shallower depths, generating the Upper North Atlantic Deep Water (UNADW). Such change in the deep circulation allows a stronger intrusion of South Oceanic Waters (SOW) at 
northern latitudes (Fig. 1), for which the aging effect has shifted their carbon isotopic composition to negative values. The mixing between these water masses (SOW and UNADW) led to lower $\delta^{13} \mathrm{C}$ values at equatorial latitudes (Duplessy et al., 1988; Sarnthein et al., 1994; Flower et al., 2000).

A schematic pattern of changes in the Atlantic deep-water masses circulation can even be drawn by using their isotopic compositions, as the result of mixing between two endmembers, with high $\delta^{13} \mathrm{C}\left(>0.5 \%\right.$ ) and low $\delta^{18} \mathrm{O}$ (around $2.5 \%$ ) values, attributed to interglacial North Atlantic Deep Waters (NADW), and lower $\delta^{13} \mathrm{C}\left(<0.5 \%\right.$ ) and higher $\delta^{18} \mathrm{O}$ ( 4.5\%o), attributed to glacial South Oceanic Waters (SOW) (Duplessy and Shackleton, 1985; Curry et al., 1988; Sarnthein et al., 1994; Flower et al., 2000; Curry and Oppo, 2005) (Fig. 1). Such isotopic oscillations have been observed over tens to hundreds of thousands year time scales (Raymo et al., 1997), but also for millennial-scale events over the last climatic cycle, shifting from warm to cold climatic conditions, associated to abrupt NADW circulation changes (e.g., Vidal et al., 1999; Shackleton et al., 2000).

As described previously, glacial-interglacial variations of global oceanic $\delta^{13} \mathrm{C}$ values could also record the expansion and contraction of the terrestrial biosphere (Maslin and Thomas, 2003). However, the consequence of such an effect might have been inadequate for the MPT time period. Indeed, for the LGM-Holocene transition, a 1\% change in the global $\delta^{18} \mathrm{O}$ sw value has been accompanied by a $0.3 \%$ change in the global $\delta^{13} \mathrm{C}$ value. Since the $\delta^{18} \mathrm{O}$ difference between successive glacial across the MPT time interval is considerably smaller than across the last deglaciation, it seems fair to assume that the additional carbon input from the larger ice sheets was also smaller than $0.3 \%$. This hypothesis is thus not sufficient to explain the entire decrease in benthic $\delta^{13} \mathrm{C}$ values observed for successive glacial periods across the MPT.

In order to investigate these deep-water isotopic composition changes and to distinguish the shorter-term fluctuations (e.g. glacial- interglacial deep oceanic circulation changes) from the MPT shift (possibly linked with atmospheric circulation changes), we present here a study of a deep marine core from the tropical Atlantic Ocean, covering the past 1.10Ma. Isotopic analyses of stable isotopes $\left(\delta^{18} \mathrm{O}\right.$ and $\left.\delta^{13} \mathrm{C}\right)$ were made on benthic foraminifera to characterize variations in the isotopic composition of deep-water masses. The core is located along the north western African margin and heavily influenced by atmospheric dust plumes from the Sahara desert. This allows us to study aridity changes over the African 
continent in parallel with the stable isotope shifts and therefore to test the global aridity hypothesis.

\section{Setting and methods}

Core MD03-2705 is located in the eastern tropical Atlantic Ocean $\left[18^{\circ} 05.81^{\prime} \mathrm{N}\right.$; $21^{\circ} 09.19^{\prime} \mathrm{W} ; 3085$ meters below sea floor (mbsf)]. The area is sensitive enough to record the balance between the NADW and the SOW water masses (Fig. 1). Previous estimates of mean accumulation rate of about $3.4 \mathrm{~cm} / \mathrm{ka}$ (Jullien et al., 2007; Tisserand et al., 2009) date the oldest part of this 37-m-long core at greater than 1 million years. The core was retrieved from a bathymetric dome, $300 \mathrm{~m}$ above the surrounding seafloor, thus preventing possible perturbations of the sediment from gravity and bottom currents (Jullien et al., 2007).

Benthic foraminifera have been handpicked under stereomicroscope from dry sediment sieved at $150 \mu \mathrm{m}$. The sampling interval was $10 \mathrm{~cm}$ and splitting of the dry samples was done when weight exceeded $0.5 \mathrm{~g}$. A maximum of 4 splits were made for sample at 1.022 Ma $(1.8 \mathrm{~g})$. Total amount of picked individuals per sample ranges from 81 at 0.910 Ma to 521 at $0.968 \mathrm{Ma}$ (mean 218). The number of counted specimens per sample has been normalised to sample weight. Data presented in this study are limited to those of the Benthic Foraminiferal Number (BFN) that shows the total number of individuals per gram of dry sediment and Uvigerina peregrina abundance changes which are considered as an indicator of surface productivity (Lutze and Coulbourn, 1984, Loubere, 1991).

Isotopic analyseswere made on monospecific samples of the bathyal epifaunal species of benthic foraminifera Planulina wuellerstorfi, and are therefore suitable to record variations in the deep-water isotopic composition. For each sample, 2 to 3 individuals were picked and dissolved in acid via the Micromass Multiprep autosampler system. The resulting carbon dioxide gas was subsequently analysed against the international reference standard NBS 19, using an Optima Micromass mass spectrometer. Measurements were carried out at the Bordeaux 1 University, within the EPOC isotopic laboratory. Triplicate measurements were made for each depth horizon $(1 \mathrm{~cm})$ to reduce uncertainties. The analytical precision is better than $0.05 \%$ for $\delta^{18} \mathrm{O}$ and $0.03 \%$ for $\delta^{13} \mathrm{C}$. A $+0.64 \mathrm{mil}^{-1}$ correction factor was applied to Planulina wuellerstorfi $\delta^{18} \mathrm{O}$ values, according to previous calibration studies (Shackleton and Opdyke, 1973; Duplessy et al., 1984). No correction is necessary for Planulina wuellerstorfi $\delta^{13} \mathrm{C}$ values. 
Major elements were measured in the bulk sediment using the Bremen XRF-Cortex facility, with a 1-cm step resolution (Jullien et al., 2007). Here, we focus on the titanium (Ti) record as a tracer of terrigenous supply (Richter et al., 2006) derived from preferential aeolian contributions (Itambi et al., 2009). The percentage of calcium carbonate is based on the $\mathrm{Ca}$ record, using a previously established calibration (Tisserand et al., 2009), that links XRFbased $\mathrm{Ca}$ measurements with the classical volumetric method using Bernard calcimeter (Huelsemann, 1966; Muller and Gatsner, 1971). Biogenic opal is a minor to negligible component of the sediment (less than 10\%) in this area (deMenocal et al., 2000). A first-order approximation of the dust content is obtained by assuming that the non-carbonate fraction represents the dust fraction as proposed by Jullien et al. (2007) and Tisserand et al. (2009), as well as by deMenocal et al. (2000) for the neighboring marine core ODP-658.

According to this hypothesis, and in a first-step approach, the concentration of terrigenous particles is estimated using the following relationship:

Semi-quantitative quartz content estimates in the clay-mineral fraction have been carried out using X-ray diffraction at the University of Lille. Samples were prepared following the protocol of Bout- Roumazeilles et al. (1999). X-ray diagrams were obtained using a BRUKER D4 Endeavor in association with the Lynxeye fast detector $(\mathrm{Cu} \mathrm{X}$-ray tube; $35 \mathrm{kV}$ voltage; $30 \mathrm{~mA}$ intensity). XRD runs were performed routinely for each sample between 2.49 and $32.49^{\circ} 2 \theta$ ) on air-dried samples. Quartz intensity (in counts per second) was measured on the $4.26 \AA$ peak using the Macintosh MacDiff ${ }^{\circ} 4.2 .5$ software (Petschick, 2000).

For paleomagnetic analyses, u-channels were sampled in the deepest part of the core, between $27 \mathrm{mbsf}$ and $29.5 \mathrm{mbsf}$ and below $33 \mathrm{mbsf}$. The analysis of the natural remanent magnetization (NRM) was conducted using a 755-R 2G-cryogenic magnetometer equipped with high-resolution pick-up coils within the $\mu$-metal shielded room of LSCE (Weeks et al., 1993). Stepwise alternating field demagnetization was conducted with 13 successive steps from 0 to $80 \mathrm{mT}$. The direction of the characteristic remanent magnetization and the mean angular deviation (MAD) were determined using a PCA analyses (Kirschvink, 1980; Mazaud, 2005).

Stratigraphy of the upper part of core MD03-2705, covering the last two climatic cycles, has been published in Jullien et al. (2007) and in Tisserand et al. (2009). A new 
stratigraphy, based on a fifthorder polynomial regression, is proposed for the past $0.22 \mathrm{Ma}$ (Matsuzaki et al., 2011). Stratigraphy of the lower part of the core was developed by tuning the $\delta^{18} \mathrm{O}$ benthic record to the LR04 reference record (Lisiecki and Raymo, 2005), using the Analyserie program (Paillard et al., 1996) (Fig. 2). The $\delta^{18} \mathrm{O}$ benthic record in core MD03 2705 is offset by a relatively constant value of $-0.5 \%$ relative to the LR0 4 record. The constancy of this difference is remarkable, given that Lisiecki and Raymo (2005) used multiple benthic records from different cores to build their stack, while MD03-2705 $\delta^{18} \mathrm{O}$ curve originates from a single core.

Stratigraphy of the lower part of core MD03-2705 is further constrained using the paleomagnetic record. Three main polarity reversals are identified with a MAD value very rarely exceeding $7-8^{\circ}$ (maximum value: $16^{\circ}$ ): a reverse to normal polarity centered around 35.85 mbsf, a normal to reverse polarity around $33.60 \mathrm{mbsf}$ and a reverse to normal polarity at $28.30 \mathrm{mbsf}$. These three polarity reversals correspond to the lower and upper Jaramillo and to the Matuyama/Bruhnes reversals. They occur during Marine Isotopic Stages (MIS) 31, 27 and 19 respectively, consistent with previous studies (Shackleton et al., 1990; Horng et al., 2002). The ages assigned to these horizons in core MD03-2705, when reported on the LR04 scale (1.07 Ma, 0.988 and $0.781 \mathrm{Ma}$, respectively, for 35.85, 33.6 and $28.3 \mathrm{mbsf}$ ) (Horng et al., 2002), are consistent within about $5 \mathrm{ka}$ uncertainty with the radiometric ages of the reversals at $1.053 \pm 6 \mathrm{Ma}, 0.986 \pm 5 \mathrm{Ma}$ and $0.779 \pm 2 \mathrm{Ma}$ (Singer et al., 1999 and references therein, Singer and Brown, 2002). All of the chrono-stratigraphic information for this core is internally consistent.

Unfortunately, the oldest sample extracted from core MD03-2705 (1.1 Ma) is not old enough to cover the whole MPT time interval, starting around 1.25 Ma according to Clark et al. (2006). Our record is therefore missing the background variations that lead up to this transition, and might possibly miss some events which could had have higher amplitude than the ones discussed in this work. Meanwhile, the largest changes recorded during the MPT are usually centered around $0.9 \mathrm{Ma}$, well within our record.

\section{Results}

\section{Continental aridity proxies}

The carbonate-free fraction of the core is a mixture of clay minerals and fine silt-sized quartz brought by the winds, along with rare freshwater diatoms and phytoliths. Because of 
224 low amounts of biogenic opal in the sediment, the aeolian dust fraction was estimated by 225 difference between the total and the $\mathrm{CaCO}_{3}$ fraction (see setting and method section). This approximation is supported by the XRF measurements of terrigenous elements such as $\mathrm{Ti}$ in the bulk sediment, which show a very good correlation with the percentage

of the terrigenous fraction (Fig. 2).

The terrigenous percentages may not solely reflect changes in dust inputs as it is also dependant on $\mathrm{CaCO}_{3}$ productivity and sedimentation, including possible dissolution effects. 231 The carbonate microfossils (foraminifera), however, present no imprint of dissolution. 232 Moreover, in a previous paper focusing on MIS 6, specific counts (on smear slides) of aeolian quartz particles in core MD03-2705, have clearly shown the link between aeolian inputs and terrigenous index $(100 \%-\mathrm{CaCO} 3)$ (Tisserand et al., 2009). Here, the good correlation between the aeolian terrigenous fraction and the quartz content estimates in the clay-mineral fraction during the MPT also supports the validity of the assumption that the percentage of mineral dust primarily reflects an intensification of the aeolian terrigenous supply, which can be interpreted in this particular sedimentary setting as variations in aridity (Rea, 1994), at 239 least for this period.

Ti variations, together with the terrigenous particle concentrations and sedimentation rate variations are compared over the past 1.1 Ma in Figure 2. Some rapid increases of the sedimentation rate are found during glacial MIS 28, 12, 6 and 2 periods. During MIS 28 (around $1.025 \mathrm{Ma}$ ), the sharp increase is clearly linked to an exceptional volcanic event, marked by an ash layer. Both the amount of $\mathrm{Ti}$ and the terrigenous content records proxies record one of their highest values within the ash layer (Fig. 2). Otherwise, variations in the sedimentation rates are rather low and steady. A strong similarity between the terrigenous proxies and $\delta^{13} \mathrm{C}$ benthic curve is clear for the earliest part of the record, from 1.1 Ma to 0.7 ka while discrepancies appear for the latest part, from $700 \mathrm{ka}$ to present day (Fig. 2). Within the MPT transition, between $1 \mathrm{Ma}$ and $0.9 \mathrm{Ma}$, glacial periods (from MIS 26 to MIS 22) are characterized by a progressive increase in both terrigenous proxies. Variability decreases in both records to a plateau within MIS 15 and MIS 13, i.e. between 0.60-0.45 Ma.

Deep-water masses isotopic signature

We defined time intervals corresponding to full glacial and interglacial periods for the last 1.1 Ma in order to identify the two primary end-member water masses (i.e., similar to 
NADW and SOW). Climatic transitions (i.e., terminations/deglaciations), during which the water masses mixing readjustment occurs, have been removed in this operation. The selected time periods, and the corresponding depth intervals, are presented in Table 1.

An $\mathrm{X}-\mathrm{Y}$ plot of $\delta^{18} \mathrm{O}$ values and $\delta^{13} \mathrm{C}$ values provides a clear graphical separation of interglacial and glacial periods (Fig. 3). Interglacial periods, concentrated on the upper part of the graph, are characterized by low $\delta^{18} \mathrm{O}$ and high $\delta^{13} \mathrm{C}$ values, while glacial periods, on the lower part of the graph, are identified by high $\delta^{18} \mathrm{O}$ and low $\delta^{13} \mathrm{C}$ values. Interglacial values are scattered around the NADW reference value, in agreement with the modern hydrology off the Mauritanian margin. Glacial periods conversely show a scattering around the SOW reference value.

For the glacial values of this scatter plot, some isotopic differences can be observed through time, defined as clusters (Fig. 3) in the following description. For oldest glacials, i.e. fromMIS 32 to 28 , isotopic values are in between the two end-member values (Fig. 3). The lowamplitude $\delta^{18} \mathrm{O}$ and $\delta^{13} \mathrm{C}$ variations characterizing MIS 32 to 28 suggest rather small glacial-interglacial deep-water masses variations (Fig. 2). The MPT (from cluster MIS 28-32 to cluster MIS24-20 in Fig. 3) is marked by a clear shift in range of $\delta^{13} \mathrm{C}$ values with lower values during both glacial and interglacial periods compared to the previous intervals, while the total amplitude of the $\delta^{18} \mathrm{O}$ signal is only slightly enriched. The most recent period, from MIS 16 to 2, shows a shift back toward higher $\delta^{13} \mathrm{C}$ values for both glacial and interglacial periods. Only MIS 12, within this recent period, experiences $\delta^{18} \mathrm{O}$ and $\delta^{13} \mathrm{C}$ isotopic values comparable to those found within MIS 32 to MIS 28 (Fig. 2). This explains the overlap between these last two clusters (on the $\mathrm{X}-\mathrm{Y}$ plot, Fig. 3). The $\delta^{13} \mathrm{C}$ signal thus displays a peculiar temporary feature over the MPT interval (from cluster MIS 28-32 to cluster MIS 2420), with both glacial and interglacial-depleted values (Figs. 2 and 3). Contrastingly, the glacial $\delta^{18} \mathrm{O}$-values increased during the MPT and progressively reached the recent glacial signature (MIS 16 to 2). Meanwhile the interglacial $\delta^{18} \mathrm{O}$ values remained rather stable (even slightly decreasing) over the MPT interval compared to the increase observed on the more recent periods (MIS 16 to 2), when the $\delta^{18} \mathrm{O}$ amplitude reached its maximum actual range.

\section{Discussion}


For the deep-water carbon isotopic composition, a marked depletion is observed in core MD03-2705 between 1.10 and $0.80 \mathrm{Ma}$, with the lowest $\delta^{13} \mathrm{C}$ values reached during MIS 24, 22 and 20 (Fig. 2). This drop in the deep marine $\delta^{13} \mathrm{C}$ values is in complete agreement (in both timing and amplitude) with what was observed in the nearby marine core ODP664 (Raymo et al., 1997). In marine record MD03-2705, a strong similarity in shape between the terrigenous content and $\delta^{13} \mathrm{C}$ benthic curve can be observed for the earliest part of the record, from 1.1 Ma to $700 \mathrm{ka}$, while discrepancies appear for the latest part, from $700 \mathrm{ka}$ to present day (Figs. 2 and 5). For the MPT time interval, between 1.0 and $0.7 \mathrm{Ma}$, the marked peaks in the $\delta^{13} \mathrm{C}$ benthic record appear to be in phase with increases in the Ti content, the terrigenous percentage and semi-quantitative quartz content records (Fig. 6). Lag-correlation analysis (using MATLAB software) between the $\delta^{13} \mathrm{C}$ benthic and terrigenous content records between 1.0 and $0.7 \mathrm{Ma}$ reveals a maximum correlation of 0.55 for a 4000 -yr lead of the terrigenous signal (Fig. 4). The relatively weak correlation suggests that, while a clear link exists between continental aridity and the $\delta^{13} \mathrm{C}$ benthic signature, this link is probably not direct (West African terrigenous signal possibly leading global aridification) and that other processes are probably involved in the carbon isotopic changes of deep-water masses.

As shown by the $\delta^{18} \mathrm{O}$ benthic record, the MPT corresponds to progressively colder glacial conditions, characterized by the building of larger continental ice sheets. As suggested by paleodata from the equatorial Atlantic Ocean (deMenocal, 1995; Jullien et al., 2007; Mulitza et al., 2008), as well as modelling results (Tjallingii et al., 2008; Kageyama et al., 2009), a strengthening of the atmospheric circulation cells, accompanied by a southward shift in the pattern of the Inter-Tropical Convergence Zone (ITCZ), is expected during these colder periods. The southward shift of the ITCZ would have extended the arid belt further south in Northwest Africa, and is likely to have increase wind stress, as observed during the last two climatic cycles (Jullien et al., 2007; Tisserand et al., 2009; Matsuzaki et al., 2011). Increasing values of dust content are consistent with these changes (Fig. 4). The hypothesis proposed by Raymo et al. (1997) seems to be supported by our Mauritanian margin record. Indeed, an extension of the arid belt associated with stronger winds blowing westward over the African continent might have increased the input from a depleted ${ }^{13} \mathrm{C}$ carbon reservoir into the ocean, contributing to the general lower $\delta^{13} \mathrm{C}$ benthic values.

A putative atmospheric circulation change during the MPT, associated with a southward shift in the migration pattern of the ITCZ, may have directly impacted the local oceanic environment, and thus the benthic $\delta^{13} \mathrm{C}$ signature. Today, strong upwelling takes 
320 place on the Mauritanian margin, which affects surface $\delta^{13} \mathrm{C}$ values of dissolved inorganic 321 carbon via stronger productivity (Mackensen and Bickert, 1999). Although core MD03-2705 322 is not located directly within the upwelling cells, some filaments of upwelled nutrientenriched waters could reach our site, during specific periods (Matsuzaki et al., 2011). In the context of sea-level falls during glacial periods, the geographic influence of upwelled waters, due to the westward Ekman deviation of the Canary Current, might have shifted offshore toward the outer shelf and upper slope (Bertrand et al., 1996), moving the productive areas off-shore as well (Martinez et al., 1996). In addition, stronger westward winds could have increased the strength of the upwelling, increasing the phytoplankton productivity. U. peregrina generally appears more abundant during glacial periods such as MIS 30, 28 and 26 when Ti content is also higher (Fig. 6). This is similar to what has been observed for the late quaternary in the South Atlantic Ocean by Schmiedl and Mackensen (1997). This increase in the amount of U. peregrina reflects higher oceanic productivity during MIS 30, 28 and 26 that could be associated with a more vigorous upwelling due to stronger winds blowing from the east. The later peak of U. peregrina (Fig. 6f) occurring during MIS 28 is most probably related to enhanced fertilization of surface water by volcanic ashes found during this interval (confirmed by magnetic susceptibility) rather than upwelling intensity. Meanwhile, no clear changes are observed while entering into colder glacial periods within the MPT (e.g. MIS 24). The direct influence of lower sea level on the paleoproductivity at the MD 03-2705 core site is therefore uncertain. To further investigate the possible changes and transfer of the carbon isotopic signal from the surface to the deep water, future work should focus on the isotopic and elemental characterization of the thermocline layer. $\mathrm{A} \delta^{13} \mathrm{C}$ record of different planktonic foraminifera species of core MD03-2705 is required to test this hypothesis.

The contribution of the West African margin aridity alone would obviously be too small to affect the global signature of the whole oceanic deep waters. Meanwhile, other paleorecords help to extent such hypothesis to the rest of the African continent. For the Benguela basin (ODP 1084) along the south tropical Atlantic African coast, intensification of the upwelling cells has been observed during the MPT, and linked with the aridification of the African continent (Marlow et al., 2000). In the Angola basin (ODP 1075), vegetation changes of the African continent have been recorded as early as $1.05 \mathrm{Ma}$ (Dupont et al., 2001). For a neighbouring core, a record of African $\mathrm{C} 4$ plant abundance, derived from compound-specific carbon isotope analysis of wind-transported terrigenous plant waxes, confirms some changes in the atmospheric moisture content during the MPT (Fig. 6) (Schefuß et al., 2003). The 
abundance of C4 plants, found predominantly in tropical savannahs and semi-deserts, seems to be directly linked with the sea surface temperature record and the atmospheric moisture content. The establishment and persistence of $\mathrm{C} 4$ grassland around $0.9 \mathrm{Ma}$ has been explained by a large-scale aridification of the African continent during this time period (Schefuß et al., 2003). Despite uncertainties linked to different age scales, increases in C4 percentage in marine core ODP1077 in the Angola basin seem to be in phase with wind-strengthening proxies ( $\mathrm{Ti}$ and Quartz counts) in core MD03-2705 off the Mauritanian margin (Fig. 6). The hypothesis of a southward shift of the ITCZ, leading to aridification and erosion of previously moist areas, is in agreement with the absence of any typical arid markers within the clay mineral association in our record. Indeed African arid sources provide fibrous clay minerals as palygorskite or sepiolite (Bout-Roumazeilles et al., 2007; Jullien et al., 2007) that are not particularly abundant over the MPT.

\section{The carbon isotopic MPT depletion—a response to an increase in global aridity?}

As discussed previously, an expansion of the mean global ice volume could have occurred for each successive glacial interval within the MPT time interval, dragging a perennial polar front southward. This latitudinal shift might have forced the southward migration of NADW convection centers, reducing the convection efficiency, as is observed for recent glacial periods. The subsequent change in the latitudinal distribution of deep-water masses would have impacted the $\delta^{13} \mathrm{C}$ benthic record in core MD03-2705, assuming that the deep-water masses are characterized by a unique isotopic signature (high $\delta^{13} \mathrm{C}$ and low $\delta^{18} \mathrm{O}$ for NADW, and low $\delta^{13} \mathrm{C}$ and high $\delta^{18} \mathrm{O}$ for SOW). The reduction of NADW formation during each successive glacial interval within the MPT might have allowed the northward penetration of the SOWfrom 1.0 to $0.8 \mathrm{Ma}$, producing noticeable $\delta^{13} \mathrm{C}$ depletion, along with a $\delta^{18} \mathrm{O}$ enrichment in the MD03-2705 benthic isotopic record. While such shift is clearly observed in the glacial benthic $\delta^{13} \mathrm{C}$ values from MIS 30 to MIS 24 (Fig. 2), only a slight amplitude change appears in the glacial benthic $\delta^{18} \mathrm{O}$ values for the same time interval. The strongest $\delta^{18} \mathrm{O}$-enriched value occurs during MIS 22 and MIS 16 (Fig. 2), while the $\delta^{13} \mathrm{C}$ benthic value does not present low values during MIS 16, for example. Such discrepancies appear clearly in the X-Y isotopic plot (Fig. 3), in which the post-MPT glacial cluster (MIS 24-20) lays far apart from the two end-members mixing line. As long as the most drastic amplitude changes between each MPT glacial periods are not in phase in both isotopic records of the same core, the validity of the hypothesis involving modification in the deep-water 
masses distribution along the successive MPT glacial interval is doubtful. Meanwhile, such discussion stands for glacial periods only, the role of circulation changes across glacialinterglacial transitions staying undisputed. From our data, we argue that the depletion in the $\delta^{13} \mathrm{C}$ benthic record of core MD03-2705, observed for the successive MPT glacial interval, could partly be the consequence of a global atmospheric change and its impact on the terrestrial carbon budget. However, more high-latitude benthic records covering the MPT time interval are needed for confirmation.

The 'aridity hypothesis' proposed by Raymo et al. (1997) still needs to be tested for other continents. Indeed, the decrease in carbon isotope values has been observed on a global scale, in each deep ocean basin. For the past $0.80 \mathrm{Ma}$, a clear link can be observed between global aridification as suggested by atmospheric dust content recovered from the Dome $\mathrm{C}$ ice core record (EPICA community members, 2004) and our $\delta^{13} \mathrm{C}$ benthic record. For each glacial period of increased dust content in the Antarctic ice, a depletion in the $\delta^{13} \mathrm{C}$ benthic record is observed in core MD03-2705 (Fig. 5). Meanwhile, no such global record of atmospheric dust exists for the period prior to 0.8 Ma. Some paleo-records of the East Asian Monsoon extend back one million years. These records are extracted from two red-clay and loess palaeosol sequences observed on the Chinese Loess Plateau (Sun et al., 2006), and are plotted in Figures 5 and 6 along with MD03-2705 records. In the continental Asian records, magnetic susceptibility is believed to represent amplitude and frequency of the eastern Asian summer monsoon. The mean grain size of the Chinese loess, which principally reflects the wind intensity, has been interpreted as a proxy for the intensity of monsoon circulation and aridity in sources area of dust (Xiao et al., 1992). Over the MPT, an increase in the mean grain size is observed for glacial periods MIS 22 and 24, in phase with aridity proxies from the Angola basin (ODP1077) or with wind-strength proxies in the Mauritanian margin (MD03-2705) (Fig. 6). Within the different timescale uncertainties linked to each of these palaeoclimatic records, eastern Asian Monsoon proxies suggest an enhanced winter monsoon activity (coarser grain size) during the MPT, while the summer monsoon is weak (Fig. 5). Such a configuration might have enhanced the aridity over the Asian continent, leading to the same impact over the ocean, i.e. an input from a ${ }^{13} \mathrm{C}$ depleted carbon reservoir into the ocean. The eastern Asian continental aridity (which mainly impacts the Pacific deep waters) reveals the same response when compared to the African continent aridity (which mainly impacts the Atlantic deep waters), and both might have thus triggered similar consequences on themean deep-water carbon isotopic composition. 


\section{Conclusions}

Multiproxy analysis of a marine core off the Mauritanian margin has allowed for reconstruction of variations in atmospheric and oceanic dynamics during the last $1.1 \mathrm{Ma}$. Ti and Quartz contents show past variations in African continental aridity, in agreement with the aeolian terrigenous particle concentration. Within the MPT, an increase of these proxies during consecutive glacial periods (MIS 26, 24 and 22) suggests enhanced aridity over the African continent. These results are consistent with evidence for aridification throughout the African continent, found in the Benguela basin (Marlow et al., 2000) or in the Angola basin (Schefuß et al., 2003). These terrestrial environmental changes correspond to shifts in the deep ocean carbon isotopic composition, with benthic $\delta^{13} \mathrm{C}$ minima during the same glacial periods. The proposed link calls for a larger input from the continental ${ }^{13} \mathrm{C}$ depleted carbon reservoir into the ocean as the result of the extension of $\mathrm{C} 4$ vegetation in the arid latitudinal band in Northwest Africa (due to a southern shift of the ITCZ), and facilitated by stronger winds. While the contribution of the West African increased aridity is probably too small to imprint the global deep-water carbon isotopic signature (as also indicated by the phase lag relationship between our terrigenous and $\delta^{13} \mathrm{C}$ records), it is likely indicative of a global aridification phenomenon that may have taken place during the MPT.

Similar shifts in the benthic $\delta^{13} \mathrm{C}$ have beenobserved indeepmarine cores from different oceans, during the MPT, highlighting the global aspect of such changes. While the $\delta^{18} \mathrm{O}$ benthic enrichment expresses the building of bigger continental ice sheets over the high latitudes continents (moving from a ' $41 \mathrm{ka}$ ' climatic cycle world to the ' $100 \mathrm{ka}$ world'), the $\delta^{13} \mathrm{C}$ benthic depletion has been hypothetically linked with global aridity changes (Raymo et al., 1997). On a global scale, we compare our African record with the continental loess record from Asia. For the same time interval, the Asian continent displayed an increased winter monsoon while the summer monsoon remained weak. Such a configuration is likely to have resulted in increased wind strength and aridity over the Asian continent. These two records therefore support Raymo et al.'s (1997) hypothesis of a worldwide input of carbon from the terrestrial biosphere reservoir into the ocean in order to account for the global deep-water carbon isotopic composition change during the MTP.

In the future, global circulation model runs could help to define the role of atmospheric dynamics during the MPT, and more precisely, test the hypothesis of a shifting ITCZ associated with the cold glacial stages of the MPT (Kageyama et al., 2009). 


\section{Acknowledgments}

IMAGES core MD03-2705 was recovered by the N/V Marion- Dufresne (Institut Paul

455 Emile Victor). O. Ther and J. Saint-Paul provided invaluable technical assistance. We thank 456 E. Schefuß, S. Weldeab and U. Röhl for access to the Bremen XRF core scanner (and Ti 457 measurements), as well as their financial RCOM support by the German Science Foundation 458 (DFG). We would like to warmly thank R. Robinson for cleaning up the written English. The 459 author would like to acknowledge two anonymous reviewers and associated editor $\mathrm{T}$. 460 Marchitto for their suggestions which helped to significantly improve the final manuscript. 461 Financial contribution from the INSU LEFE-EVE program is acknowledged. This is UMR 462 5805 EPOC contribution 1785.

\section{References}

465 Bertrand, P., Shimmield, G., Martinez, P., Grousset, F., Jorissen, F., Paterne, M., Pujol, C., 466 Bouloubassi, I., Buat-Menard, P., Peypouquet, J.-P., Beaufort, L., Sicre, M.-A., Lallier467 Verges, E., Ternois, Y., and other participants of the Sedorqua Program, 1996. The glacial 468 ocean productivity hypothesis: the importance of regional temporal and spatial studies. 469 Marine Geology 130, 1-9.

470 Bout-Roumazeilles, V., Cortijo, E., Labeyrie, L., Debrabant, P., 1999. Clay mineral evidence 471 of nepheloid layer contribution to the Heinrich layers in the Northwest Atlantic. 472 Palaeogeography, Palaeoclimatology, Palaeoecology 146, 211-228.

473 Bout-Roumazeilles, V., Nebout, N.C., Peyron, O., Cortijo, E., Landais, A., Masson474 Delmotte, V., 2007. Connection between South Mediterranean climate and North African 475 atmospheric circulation during the last 50,000 yr BP North Atlantic cold events. Quaternary 476 Science Reviews 26, 3197-3215.

477 Broecker, W.S., Peng, T.H., 1982. Tracers in the Sea. Lamont-Doherty Earth Obs, Palisades, 478 NY. 690 pp.

479 Clark, P.U., Archer, D., Pollard, D., Blum, J.D., Rial, J.A., Brovkin, V., Mix, A., Pisias, N.G., 480 Roy, M., 2006. The middle Pleistocene transition: characteristics, mechanisms, and 481 implications for long-term changes in atmospheric pCO2. Quaternary Science Reviews 25, 482 3150-3184. 
483 Curry, W.B., Oppo, D.W., 2005. Glacial water mass geometry and the distribution of $\delta^{13} \mathrm{C}$ of $484 \Sigma \mathrm{CO} 2$ in the Western Atlantic Ocean. Paleoceanography 20, PA1017. 485 doi:10.1029/2004PA001021.

486 Curry, W.B., Duplessy, J.-C., Labeyrie, L.D., Shakleton, N., 1988. Changes in the distribution 487 of $\delta^{13} \mathrm{C}$ of deep water $\Sigma \mathrm{CO} 2$ between the last glaciation and the Holocene. Paleoceanography $4883(3), 317-341$.

489 De Garidel-Thoron, T., Rosenthal, Y., Bassinot, F., Beaufort, L., 2005. Stable sea surface 490 temperatures in the Western Pacific warm pool over the last 1.75 million years. Nature 433, $491 \quad 294-298$.

492 deMenocal, P.B., 1995. Plio-Pleistocene African climate. Science 270, 53-59.

493 deMenocal, P.B., 2004. African climate change and faunal evolution during the Pliocene494 Pleistocene. Earth and Planetary Science Letters 220, 3-24.

495 deMenocal, P.B., Ortiz, J., Guilderson, T., Adkins, J., Sarnthein, M., Baker, L., Yarusinsky, 496 M., 2000. Abrupt onset and termination of the African Humid Period: rapid climate responses 497 to gradual insolation forcing. Quaternary Science Reviews 17, 395-409.

498 Duplessy, J.-C., Shackleton, N., 1985. Response of global deep-water circulation to Earth's 499 climatic change 135,000-107,000 years ago. Nature 316 (6028), 500-507.

500 Duplessy, J.-C., Moyes, J., Pujol, C., 1980. Deep water formation in the North Atlantic Ocean 501 during the last ice age. Nature 286, 479-481.

502 Duplessy, J.-C., Shackleton, N.J., Matthews, R.K., Prell, W., Ruddiman, W.F., Caralp, M., 503 Hendy, C.H., $1984 .{ }^{13} \mathrm{C}$ record of benthic foraminifera in the last interglacial ocean : 504 Implication for the carbon cycle and the global deep water circulation. Quaternary Research $50521,225-243$.

506 Duplessy, J.-C., Shackleton, N.J., Fairbanks, R.G., Labeyrie, L., Oppo, D., Kallel, N., 1988. 507 Deepwater source variations during the last climatic cycle and their impact on the global 508 deepwater circulation. Paleoceanography 3 (3), 343-360.

509 Dupont, L., Donner, B., Schneider, R., Wefer, G., 2001. Mid-Pleistocene environmental 510 change in tropical Africa began as early as 1.05 Ma. Geology 29 (3), 195-198.

511 Epica community members, 2004. Eight glacial cycles from an Antarctic ice core. Nature 512 $429,623-628$. 
513 Flower, B.P., Oppo, D.W., McManus, J.F., Venz, K.A., Hodell, D.A., Cullen, J.L., 2000.

514 North Atlantic intermediate to deep water circulation and chemical stratification during the past 1 Myr. Paleoceanography 15 (4), 388-403.

516 Hoogakker, B.A., Rohling, E.J., Palmer, M.R., Tyrrell, T., Rothwell, R.G., 2006. Underlying causes for long-term global ocean $\delta^{13} \mathrm{C}$ fluctuations over the last $1.20 \mathrm{Myr}$. Earth and Planetary Science Letters 248, 15-29.

519 Horng, C.S., Lee, M.Y., Pälike, H., Wei, K.Y., Liang, W.T., Iizuka, Y., Torii, M., 2002. 520 Astronomically calibrated ages for geomagnetic reversals within the Matuyama chron. Earth 521 Planets Space 54, 679-690.

522 Huelsemann, J., 1966. On the routine analysis of carbonates in unconsolidated sediments. 523 Journal of Sedimentary Petrology 36 (2), 622-625.

524 Itambi, A.C., von Dobeneck, T., Mulitza, S., Bickert, T., Heslop, D., 2009. Millennial-scale northwest African droughts related to Heinrich events and Dansgaard-Oeschger cycles:

526 Evidence in marine sediments from offshore Senegal. Paleoceanography 24, PA1205. 527 doi:10.1029/2007PA001570.

528 Jullien, E., Grousset, E.F., Malaizé, B., Duprat, J., Sanchez-Goni, M.F., Eynaud, F., Charlier, 529 K., Schneider, R., Bory, A., Bout, V., Flores, J., 2007. Low latitude 'dusty events' vs high 530 latitude 'Icy Heinrich events'? Research Quarterly 68 (3), 379-386. doi:10.1016/j. 531 yqres.2007.07.007.

532 Kageyama, M., Mignot, J., Swingedouw, D., Marzin, C., Alkama, R., Marti, O., 2009. Glacial 533 climate sensitivity to different states of the Atlantic Meridional Overturning Circulation : 534 results from the IPSL model. Climate of the Past 5, 551-570.

535 Kirschvink, J., 1980. The least-squares line and plane and the analysis of paleomagnetic data. 536 Geophysical Journal of the Royal Astronomical Society 62, 699-718.

537 Kroopnick, P.M., 1985. The distribution of $\delta^{13} \mathrm{C}$ of $\Sigma \mathrm{CO} 2$ in the world oceans. Deep-Sea 538 Research Part A 32, 57-84.

539 Lisiecki, L.E., Raymo, M.E., 2005. A Plio-Pleistocene stack of 57 globally distributed benthic $540 \quad \delta^{18} \mathrm{O}$ records. Paleoceanography 20, PA1003. doi:10.1029/2004PA001071.

541 Loubere, P., 1991. Deep-sea benthic foraminiferal assemblage response to a surface ocean 542 productivity gradient: a test. Paleoceanography 6 (2), 193-204. 
543 Lutze, G.F., Coulbourn, W.T., 1984. Recent benthic foraminifera from the continental margin 544 of northwest Africa: community structure and distribution. Marine Micropaleontology 8, $545 \quad 361-401$.

546 Mackensen, A., Bickert, T., 1999. Stable carbon isotopes in benthic foraminifera: proxies for 547 deep and bottom water circulation and new production. In: Fisher, G., Wefer, G. (Eds.), Use 548 of Proxies in Paleoceanography: Examples from the South Atlantic Ocean. Springer-Verlag, 549 Berlin Heidelberg, pp. 229-254.

550 Marlow, J.R., Lange, C.B., Wefer, G., Rosell-Mele, A., 2000. Upwelling intensification as 551 part of the Pliocene-Pleistocene climate transition. Science 290, 2288-2291.

552 Martinez, P., Bertrand, P., Bouloubassi, I., Bareille, G., Shimmield, G., Vautravers, B., 553 Grousset, F., Guichard, S., Ternois, Y., Sicre, M.-A., 1996. An integrated view of inorganic 554 and organic biogeochemical indicators of palaeoproductivity changes in a coastal upwelling area. Organic Geochemistry 24 (4), 411-420.

556 Maslin, M., Thomas, E., 2003. Balancing the deglacial global carbon budget: the hydrate 557 factor. Quaternary Science Reviews 1729-1736.

558 Matsuzaki, K.M.R., Eynaud, F., Malaizé, B., Grousset, F.E., Tisserand, A., Rossignol, L., 559 Charlier, K., Jullien, E., 2011. Paleoceanography of the Mauritanian margin during the last 560 two climatic cycles: from planktonic foraminifera to African climate dynamic. Marine 561 Micropaleontology 79, 67-79. doi:10.1016/j.marmicro.2011.01.004.

562 Mazaud, A., 2005. User-friendly software for vector analysis of the magnetization of long 563 sediment cores. Geochemistry Geophysics Geosystems 6. doi:10.1029/2005GC001036.

564 Mulitza, S., Prange, M., Stuut, J.-B., Zabel, M., vonDobeneck, T., Itambi, A., Nizou, J., 565 Schulz, M., Wefer, G., 2008. Sahel megadroughts triggered by glacial slowdowns of Atlantic 566 meridional overturning. Paleoceanography 23, PA4206. doi:10.1029/2008PA001637.

567 Muller, G., Gatsner, M., 1971. Chemical analysis. Neues Jahrbuch für Mineralogie 568 Monatshefte 10, 466-469.

569 Oppo, D.W., Lehman, S.J., 1993. Mid-depth circulation of the sub-polar North Atlantic 570 during the Last Glacial Maximum. Science 259, 1148-1152.

571 Paillard, D., Labeyrie, L., Yiou, P., 1996. Macintosh program makes time-series analysis 572 easy. EOS Transactions, Americain Geophysical Union 77 (39), 379. 
573 Petschick, R., 2000. MacDiff 4.2 Manual. MacDiff. (online). Available from: http://www. 574 geologie.uni-frankfurt.de/Staff/Homepages/Petschick/RainerE.html. (Revised 2001-05-17).

575 Ravelo, A.C., Andreasen, D.H., Lyle, M., Lyle, A.O., Wara, M., 2004. Regional climate shifts caused by gradual global cooling in the Pliocene epoch. Nature 429, 263-267.

577 Raymo, M.E., Oppo, D.W., Curry, W., 1997. The mid-Pleistocene climate transition: a deep 578 sea carbon isotopic perspective. Paleoceanography 12 (4), 546-559.

579 Raymo, M.E., Oppo, D.W., Flower, B.P., Hodell, D.A., McManus, J.F., Venz, K.A., Kleiven, 580 K. F., McIntyre, K., 2004. Stability of North Atlantic water masses in face of pronounced 581 climate variability during the Pleistocene. Paleoceanography 19, PA2008. 582 doi:10.1029/2003PA000921.

583 Rea, D.K., 1994. The paleoclimatic record provided by eolian deposition in the deep sea: the 584 geologic history of wind. Reviews of Geophysics 32, 159-195.

585 Richter, T.O., van der Gaast, S., Koster, B., Vaars, A., Gieles, R., de Stigter, H.C., de Haas, 586 H., van Weering, T.C.E., 2006. The Avaatech XRF Core Scanner: technical description and 587 applications to NE Atlantic sediments. In: Rothwell, G. (Ed.), New Techniques in Sediment 588 Core Analysis: Geol. Soc. London Spec. Publ., 267, pp. 39-50.

589 Sarnthein, M., Winn, K., Jung, S.J.A., Duplessy, J.-C., Labeyrie, L., Erlenkeuser, H., 590 Ganssen, G., 1994. Changes in east Atlantic deepwater circulation over the last 30,000 years: 591 eight time slice reconstructions. Paleoceanography 9 (2), 209-267.

592 Schefuß, E., Schouten, S., Jansen, F., Damsté, J.S., 2003. African vegetation controlled by 593 tropical sea surface temperatures in the mid-Pleistocene period. Nature $422,418-421$.

594 Schmiedl, G., Mackensen, A., 1997. Late quaternary paleoproductivity and deep water 595 circulation in the seastern South Atlantic Ocean: evidence from benthic foraminifera. 596 Paleogeography, Paleoclimatology, Paleoecology 130, 43-80.

597 Shackleton, N.J., Opdyke, N.D., 1973. Oxygen isotope and palaeomagnetic stratigraphy of 598 equatorial Pacific core V28-238: oxygen isotope temperatues and ice volumes on a 100 kyrs 599 and 1000 kyrs scale. Journal of Quaternary Research 3 (1), 39-54.

600 Shackleton, N.J., Berger, A., Peltier, W.R., 1990. An alternative astronomical calibration of 601 the lower Pleistocene timescale based on ODP Site 677. Transactions of the Royal Society 602 Edinburgh: Earth Sciences 81, 251-261. 
603 Shackleton, N., Hall, M., Vincent, E., 2000. Phase relationship between millennial-scale 604 events 64,000-24,000 years ago. Paleoceanography 15 (6), 565-569.

605 Singer, B.S., Brown, L.L., 2002. The Santa Rosa event: 40Ar/39Ar and paleomagnetic results 606 from the Valles rhyolite near Jaramillo Creek, Jemez Mountains, NewMexico. Earth and 607 Planetary Science Letters 197, 51-64.

608 Singer, B.S., Hoffman, K.A., Pringle, M.S., Chauvin, A., Coe, R.S., 1999. Dating 609 transitionally magnetized lavas of the late Matuyama Chron: toward a new 40Ar/39Ar 610 timescale of reversals and events. Journal of Geophysical Research 104, 679-693.

611 Sun, Y., Clemens, S.C., An, Z., Yu, Z., 2006. Astronomical timesclae and palaeoclimatic 612 implication of stacked 3.6-Myr monsoon records from the Chinese Loess Plateau. Quaternary 613 Science Reviews 25, 33-48. doi:10.1016/j.quascirev. 2005.07.005.

614 Tisserand, A., Malaizé, B., Jullien, E., Zaragosi, S., Charlier, K., Grousset, F., 2009. African 615 monsoon enhancement during a cold stage, Marine Isotopic Stage 6.5 (MIS6.5), 170 kyr ago. 616 Paleoceanography. doi:10.1029/2008 PA001630.

617 Tjallingii, R., Claussen, M., Stuut, J.-B., Fohlmeister, J., Jahn, A., Bickert, T., Lamy, F., Röhl, 618 U., 2008. Coherent high-and low-latitude control of the northwest African hydrological 619 balance. Nature Geosciences 1. doi:10.1038/ngeo289.

620 Vidal, L., Schneider, R.R., Marchal, O., Bickert, T., Stocker, T.F., Wefer, G., 1999. Link 621 between the north and south Atlantic during the Heinrich events of the last glacial period. 622 Climate Dynamics 15, 909-919.

623 Weeks, R., Laj, C., Endignoux, L., Fuller, M., Roberts, A., Manganne, R., Blanchard, E., 624 Goree, W., 1993. Improvements in long-core measurement techniques: applications in 625 palaeomagnetism and palaeoceanography. Geophysical Journal International 114, 651-662.

626 Xiao, J., Hongbo, Z., Zhao, H., 1992. Variation of winter monsoon intensity on the Loess 627 plateau, Central China during the Last 130,000 years : evidence from grain size distribution. 628 Quaternary Research 31 (1), 13-19. 


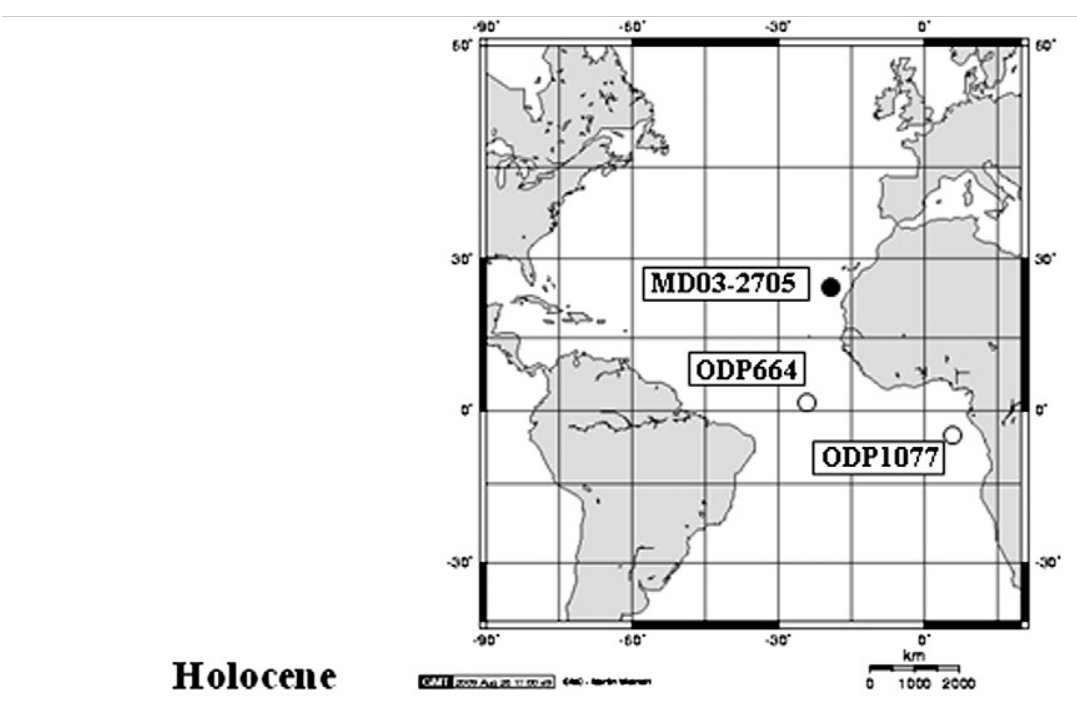

Last Glacial Maximum

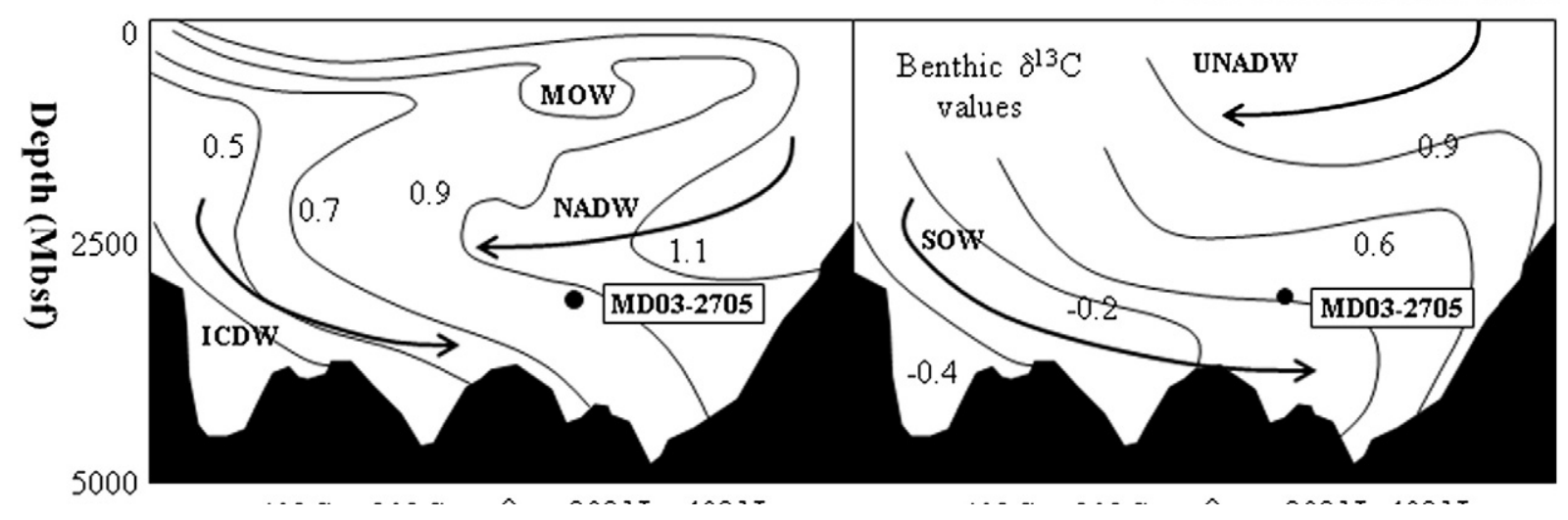

632 Figure 1. Cross sectional maps of the Atlantic ocean. Location of cores MD03-2705 (this 633 study), ODP 664 (Raymo et al., 1997) and ODP1077 (Dupont et al., 2001; Schefuß et al., $6342003)$ and carbon isotopic values $\left(\delta^{13} \mathrm{C}\right)$ of water masses. 


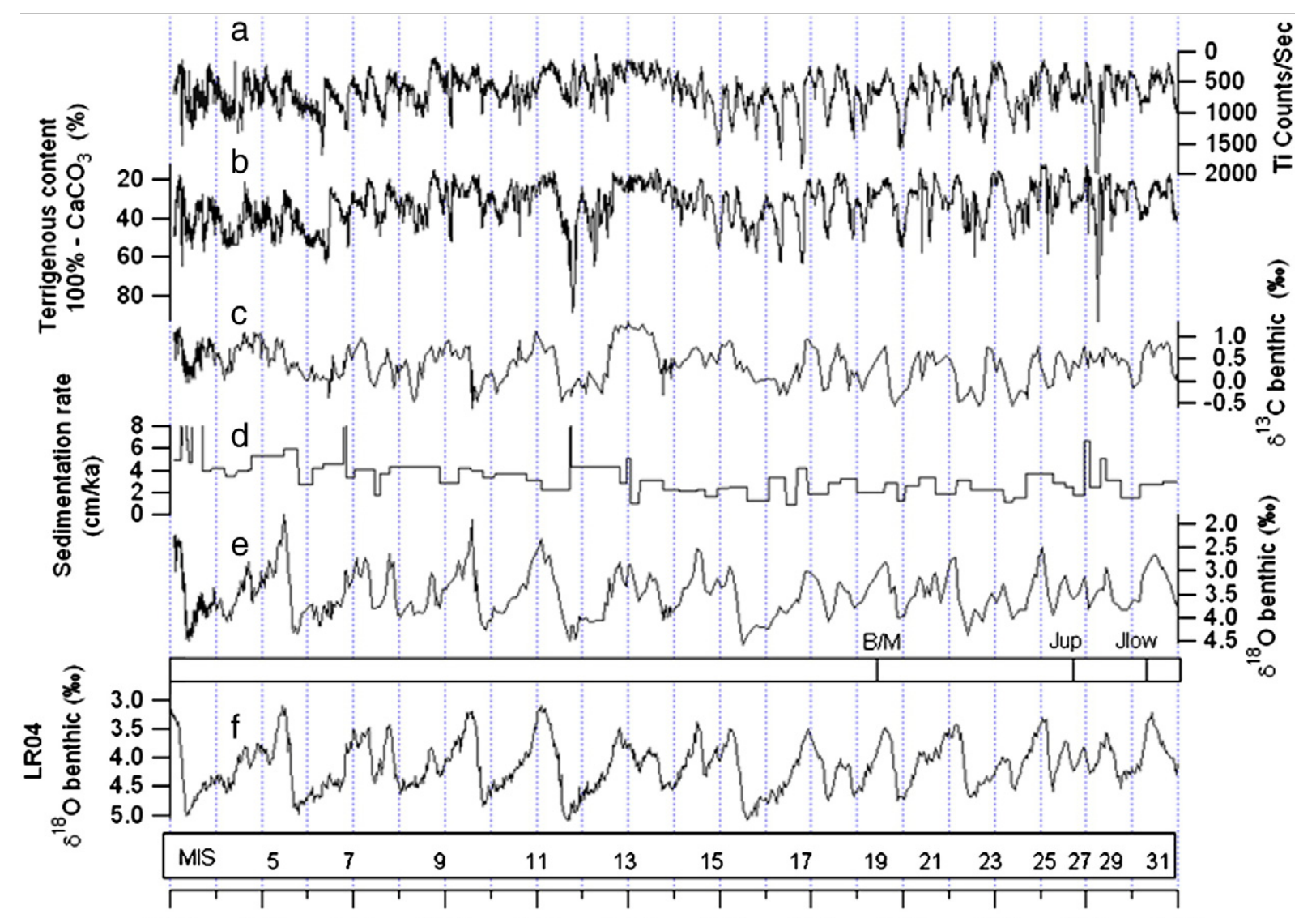

637 Figure 2. (a) Ti qualitative content (XRF) in core MD03-2705; (b) Terrigenous content 638 approximation in core MD03-2705; (c) Benthic $\delta^{13} \mathrm{C}$ record in core MD03-2705; (d) 639 sedimentation rate in core MD03-2705; (e) Benthic $\delta^{18} \mathrm{O}$ record in core MD03-2705. (f) 640 Benthic $\delta^{18} \mathrm{O}$ record from LR04 stack (Lisiecki and Raymo, 2005). Main paleomagnetic 641 horizons are marked (B/M: Bruhnes-Matuyama, Jup: upper Jaramillo, Jlow: lower Jaramillo). 


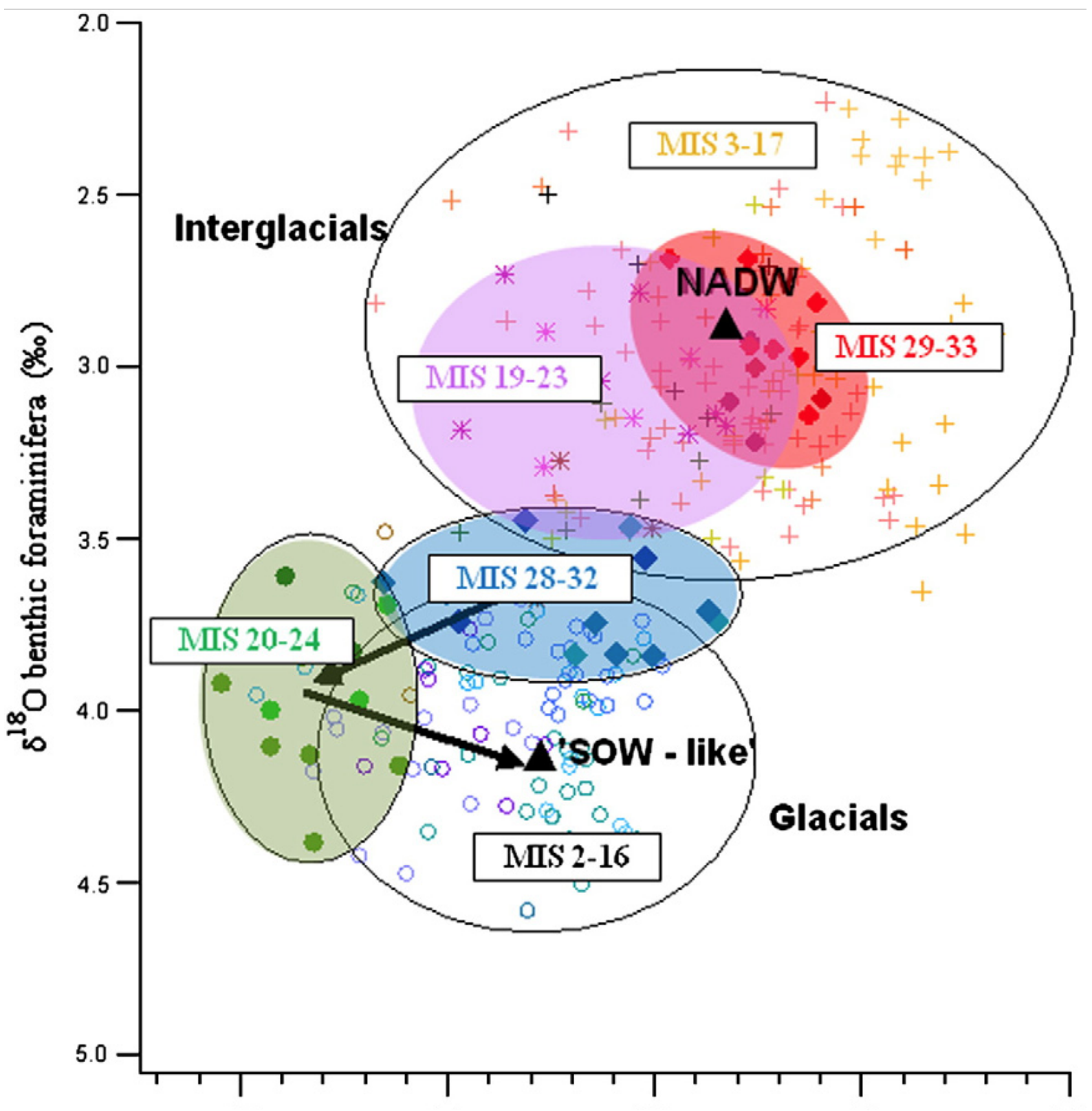

Figure 3. Isotopic composition of deep-water masses. Crosses and stars (red and pink) 645 represent interglacial periods. Diamonds and circles (blue and green) represent glacial 646 periods. We have distinguished between recent glacial periods, from MIS 2-16 (clear blue 647 circles), oldest glacial periods (blue diamonds: MIS 28-32, and plain green circles: MIS 20648 24), as well as recent interglacial intervals, from MIS 3-17 (crosses) and oldest interglacials 649 (red bold stars: MIS 29-33 and pink stars: MIS 19-23) as discussed in text. Black arrows 650 represent evolution from older time periods to younger ones. Black triangles present the 651 modern isotopic composition of NADW and of a southern water mass which isotopic 652 composition could be associated to a 'SOW-like' end-member. 


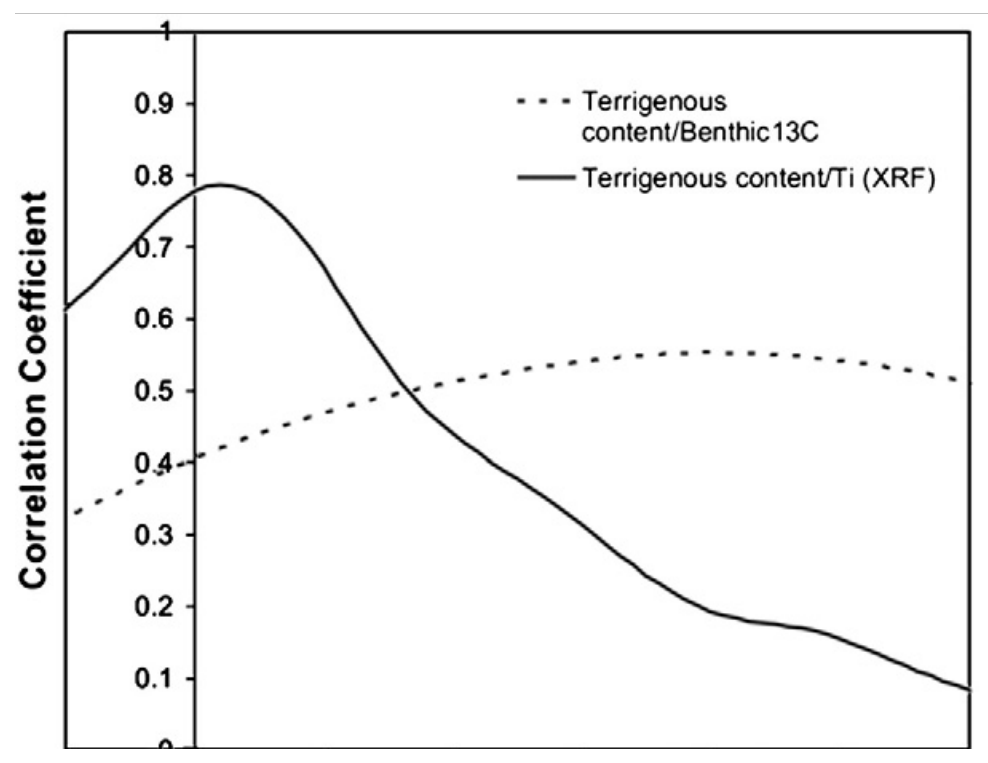

654 Figure 4. Correlation as a function of lag (years) for the interval 700-1100 kyrs between the 655 terrigenous content and the benthic $\delta^{13} \mathrm{C}$ records (dash line) and between the terrigenous 656 content and Titanium (Ti) measurement with the XRF core scanner records (plain line). 657 Maximum correlation (0.55) are achieved for a 4000-year lead of terrigenous content vs 658 benthic $\delta^{13} \mathrm{C}$. Maximum correlation (0.79) indicate a quasi-in phase relationship between 659 terrigenous content and Titanium (Ti) measurement with the XRF core scanner. 


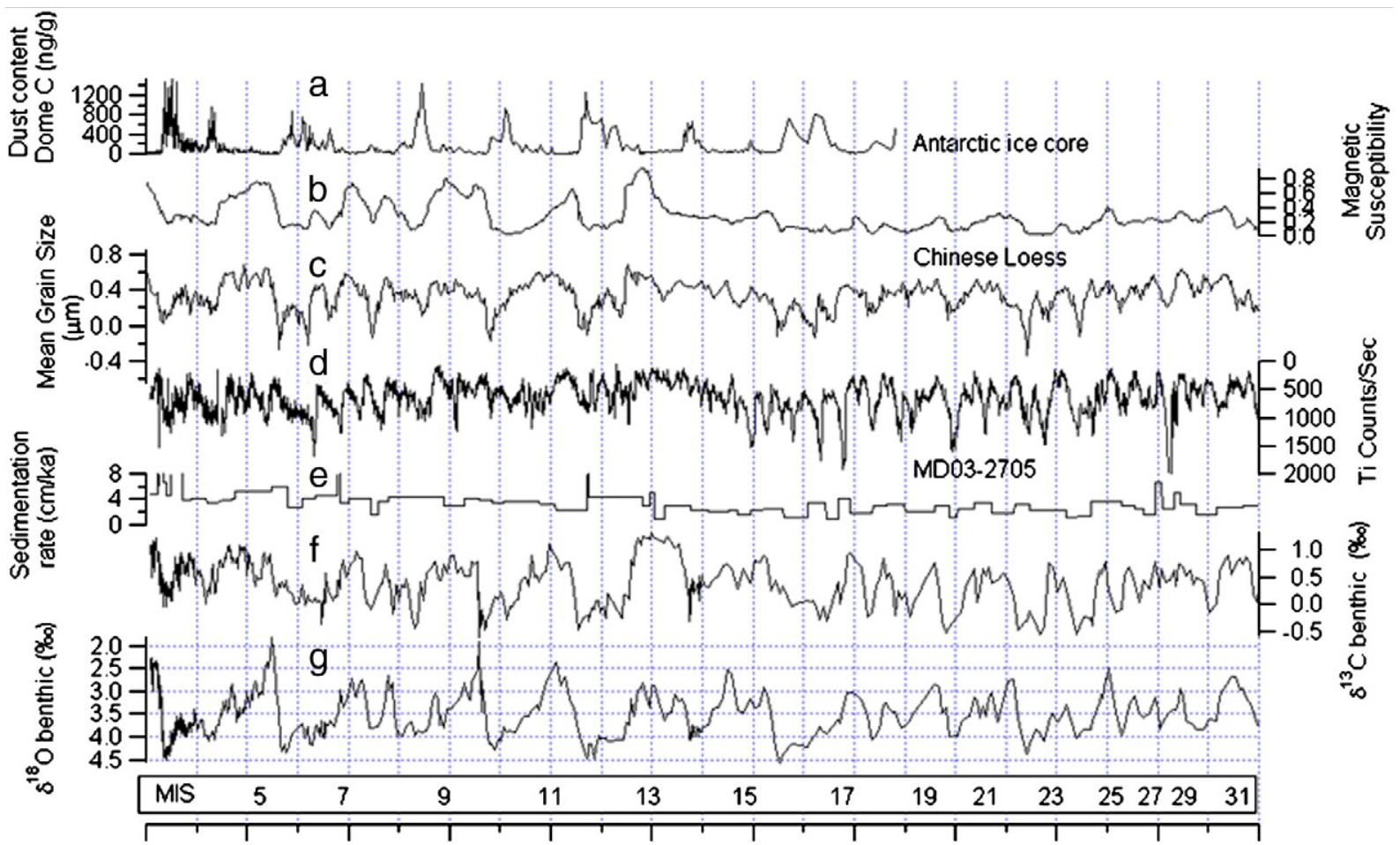

Figure 5. (a) Dust content in Dome C ice Core (Antarctica) (Epica community members, 663 2004); (b) Magnetic susceptibility of East Asian Loess (Summer monsoon proxy) (Sun et al., 664 2006); (c)Mean grain size composition of East Asian Loess (Winter monsoon proxy) (Sun et 665 al., 2006); (d) Ti qualitative content in coreMD03-2705 (aridity proxy); (e) Sedimentation rate 666 in core MD03-2705; (f) $\delta^{13} \mathrm{C}$ benthic record from core MD03-2705; (g) Benthic $\delta^{13} \mathrm{C}$ record 667 for core MD03-2705. 

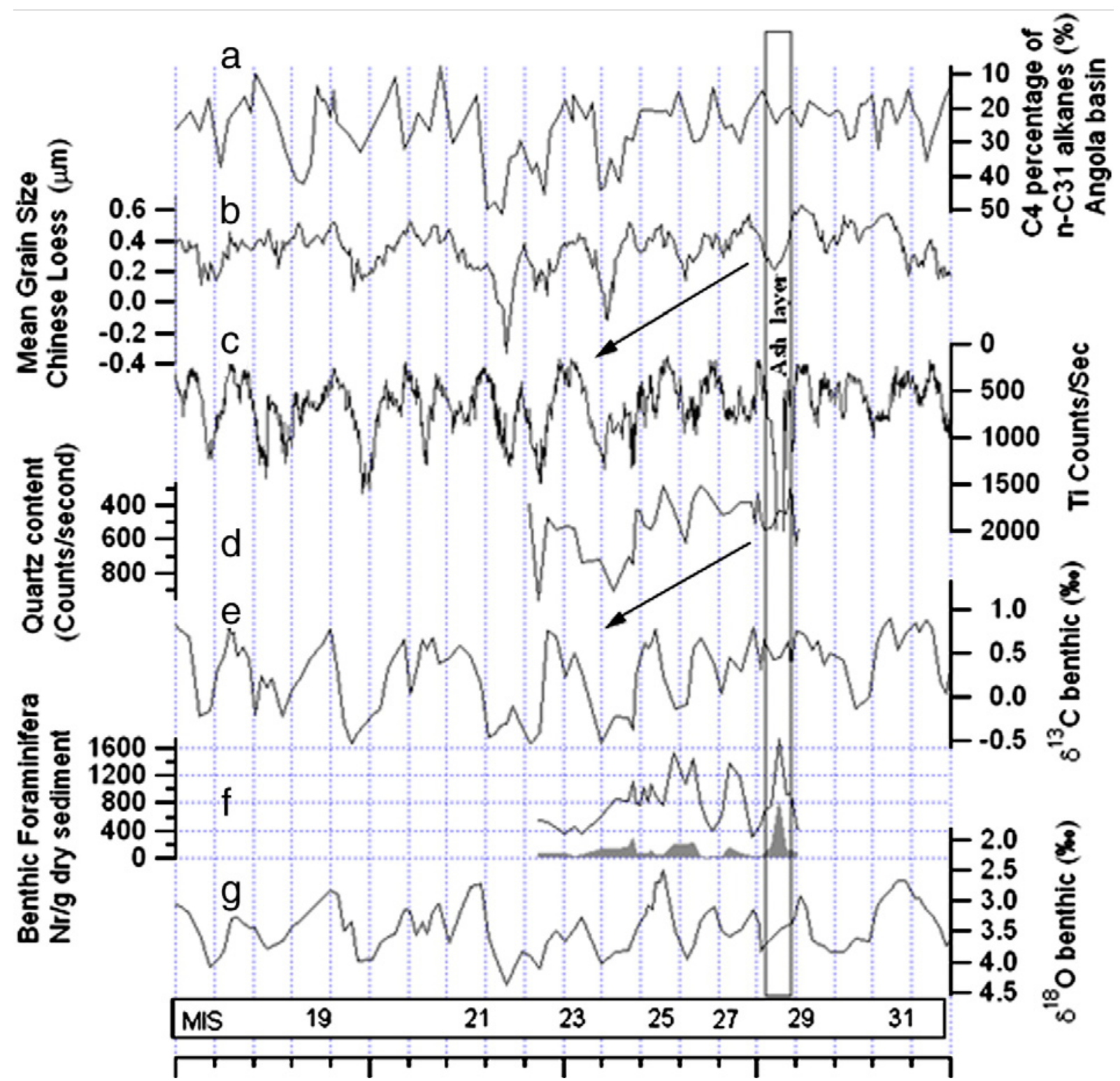

670 Figure 6. Zoom on the MPT:(a) C4 plant percentage of n-C31 alkanes (\%) from the Angola 671 basin (ODP 1077) (Schefuß et al., 2003)(b) Mean grain size composition of East Asian Loess 672 (Winter monsoon proxy) (Sun et al., 2006)(c) Ti qualitative content in core MD03-2705 673 (aridity proxy);(d) Quartz content in core MD03-2705;(e) $\delta^{13} \mathrm{C}$ benthic record from core 674 MD03-2705;(f) Benthic foraminiferal analysis in core MD03-2705. BFN (black line) and 675 Uvigerina peregrina (grey area), indicating higher paleoproductivity for high values.(g) 676 Benthic $\delta^{18} \mathrm{O}$ record for record core MD03-2705. The vertical grey band highlights the 677 volcanic ash layer found in core MD03-2705. 
680 Glacial and interglacial intervals, together with their mean isotopic values.

\begin{tabular}{|c|c|c|c|c|}
\hline M.IS. & Depth (cmbsf) & Age (cal) ka B. P. & $\delta^{18} 0$ mean value $(\%)$ & $\delta^{13} \mathrm{C}$ mean value $\left(\%_{0}\right)$ \\
\hline 1 & $0-28$ & $0-10.07$ & 2.480 & 0.961 \\
\hline 2 & $104-160$ & $18.045-21.142$ & 4.266 & 0.247 \\
\hline 3 & $218-346$ & $25.897-47.693$ & 3.767 & 0.684 \\
\hline 4 & $385-410$ & $56.917-63.134$ & 3.929 & 0.229 \\
\hline 5 & $450-720$ & $73.215-128.977$ & 2.984 & 0.747 \\
\hline 6 & $750-790$ & $134.762-141.836$ & 4.256 & 0.336 \\
\hline 7 & $1000-1220$ & $185.430-240.973$ & 3.032 & 0.563 \\
\hline 8 & $1250-1350$ & $247.711-274.666$ & 3.868 & 0.106 \\
\hline 9 & $1380-1550$ & $283.166-329.560$ & 2.929 & 0.531 \\
\hline 10 & $1580-1670$ & $337.000-362.077$ & 4.002 & -0.04 \\
\hline 11 & $1800-1860$ & $398.600-422.714$ & 2.799 & 0.767 \\
\hline 12 & $1900-2080$ & $437.000-477.134$ & 4.085 & -0.052 \\
\hline 13 & $2100-2251$ & $481.782-532,933$ & 3.205 & 1.079 \\
\hline 14 & $2271-2310$ & $538.450-556.000$ & 3.871 & 0.329 \\
\hline 15 & $2350-2440$ & $575.000-618.000$ & 3.132 & 0.627 \\
\hline 16 & $2460-2480$ & $626.000-638.000$ & 4.375 & 0.161 \\
\hline 17 & $2570-2650$ & $684.000-712.500$ & 3.301 & 0.459 \\
\hline 18 & $2660-2770$ & $718.000-755.000$ & 3.819 & 0.131 \\
\hline 19 & $2790-2850$ & $765.000-790.500$ & 3.139 & 0.203 \\
\hline 20 & $2860-2880$ & $794.000-805.902$ & 3.885 & -0.262 \\
\hline 21 & $2911-3011$ & $818.000-858.000$ & 3.033 & 0.414 \\
\hline 22 & 3041 - 3091 & $867.600-887.671$ & 4.088 & -0.349 \\
\hline 23 & $3121-3140$ & $901.341-910.000$ & 3.473 & 0.326 \\
\hline 24 & $3161-3181$ & $927.000-936.000$ & 3.752 & -0.292 \\
\hline 25 & $3221-3261$ & $944.000-952.000$ & 2.824 & 0.530 \\
\hline 26 & 3271 - 3301 & $958.000-971.000$ & 3.633 & 0.243 \\
\hline 27 & $3321-3381$ & $978.000-1001.000$ & 3.344 & 0.419 \\
\hline 28 & $3391-3421$ & $1002.500-1012.000$ & 3.659 & 0.456 \\
\hline 29 & $3451-3471$ & $1020.000-1025.200$ & 3.081 & 0.717 \\
\hline 30 & $3491-3541$ & $1031.600-1058.000$ & 3.736 & 0.290 \\
\hline 31 & $3561-3621$ & $1065.429-1087.500$ & 2.883 & 0.769 \\
\hline 32 & $3641-3661$ & $1094.500-1101.333$ & 3.582 & 0.232 \\
\hline 33 & $3671-3681$ & $1104.666-1108.000$ & 3.046 & 0.822 \\
\hline
\end{tabular}

